\title{
Effect of Downy Mildew Development on Transpiration of Cucumber Leaves Visualized by Digital Infrared Thermography
}

\author{
Miriam Lindenthal, Ulrike Steiner, H.-W. Dehne, and E.-C. Oerke
}

Institute for Plant Diseases, University of Bonn, Nussallee 9, D-53115 Bonn, Germany. Accepted for publication 19 October 2004.

\begin{abstract}
Lindenthal, M., Steiner, U., Dehne, H.-W., and Oerke, E.-C. 2005. Effect of downy mildew development on transpiration of cucumber leaves visualized by digital infrared thermography. Phytopathology 95:233-240.

Disease progress of downy mildew on cucumber leaves, caused by the obligate biotrophic pathogen Pseudoperonospora cubensis, was shown to be associated with various changes in transpiration depending on the stage of pathogenesis. Spatial and temporal changes in the transpiration rate of infected and noninfected cucumber leaves were visualized by digital infrared thermography in combination with measurements of gas exchange as well as microscopic observations of pathogen growth within plant tissue and stomatal aperture during pathogenesis. Transpiration of cucumber leaf tissue was correlated to leaf temperature in a negative linear manner $(r=-0.762, P<0.001, n=18)$. Leaf areas colonized by $P$ seu-

perature up to $0.8^{\circ} \mathrm{C}$ lower than noninfected tissue due to abnormal stomatal opening. The appearance of chlorosis was associated with a cooling effect caused by the loss of integrity of cell membranes leading to a larger amount of apoplastic water in infected tissue. Increased water loss from damaged cells and the inability of infected plant tissue to regulate stomatal opening promoted cell death and desiccation of dying tissue. Ultimately, the lack of natural cooling from necrotic tissue was associated with an increase in leaf temperature. These changes in leaf temperature during downy mildew development resulted in a considerable heterogeneity in temperature distribution of infected leaves. The maximum temperature difference within a thermogram of cucumber leaves allowed the discrimination between healthy and infected leaves before visible symptoms appeared.
\end{abstract} doperonospora cubensis exhibited a presymptomatic decrease in leaf tem-
Additional keyword: Cucumis sativus.
The obligate biotrophic oomycete Pseudoperonospora cubensis (Berk. et Curt.) Rostovzev causes downy mildew of cucurbits, a devastating disease, especially in temperate regions of the world $(30,43)$. Disease development is adapted to humid conditions; infection by zoospores requires free water on the lower leaf surface for at least $2 \mathrm{~h}$, and production of zoosporangia in the dark occurs at a relative humidity $(\mathrm{RH})$ of $>90 \%$ for at least $6 \mathrm{~h}(11,12,50)$. After penetration via stomata, haustorium formation requires as little as $4 \mathrm{~h}$, and with an appropriate day/night regime of $25^{\circ} \mathrm{C} / 15^{\circ} \mathrm{C}$, infection may result in sporangial production within 4 days.

First symptoms are small, slightly chlorotic to bright yellow areas on the upper surface of the leaves. As these lesions expand, they may remain chlorotic or, depending on environmental conditions, become necrotic and brown. Lesions are angular and bound by leaf veins. Under favorable conditions, sporangiophores appear on the lower leaf surface and are formed through the stomata. Brown or colorless zoosporangia are subsequently produced. Further development of lesions results in the necrotization of progressively larger leaf areas, and in a few days the entire leaf may be dead.

Infection by biotrophic pathogens results in many changes in the metabolic processes of plant tissue including shifts in respiration, photosynthesis, and transpiration (31). All these changes are interrelated, some occur simultaneously, others form a sequence of alterations reflecting different stages in disease development. In host-pathogen interactions involving biotrophic pathogens, the allocation of organic and inorganic nutrients for the production of fungal biomass is crucial. Water loss from infected leaf areas can

Corresponding author: M. Lindenthal; E-mail address: miriam.lindenthal@ gmx.de

DOI: 10.1094/PHYTO-95-0233

(C) 2005 The American Phytopathological Society increase due to destruction of the leaf cuticle (5), increased permeability of leaf cell membranes (7), or inhibition of stomatal closure $(17,47)$. Reduction of transpiration may result from stomatal closure (7), obstruction of xylem elements and stomata (5), and defoliation.

During pathogenesis, oomycetes inciting downy mildew often cause a sequence of different symptoms and signs; after infection, the pathogen colonizes the mesophyll, forming haustoria in parenchymatic cells; first disease symptoms appear on the upper leaf surface without loss of vitality in plant cells (48); necrotization of colonized tissue occurs only after intensive pathogen growth and starts in the center of the lesions; and under ambient conditions, sporulation of downy mildew pathogens is typically located in the transition zone at the margin of these lesions displaying the front line of the pathogen's growth into living plant tissue. These temporal spatial dynamics in producing disease symptoms seem to be rather limited to downy mildew pathogens, which have to rapidly colonize new healthy leaf areas-despite being biotrophic-because the pathogen severely damages the colonized plant tissue (48).

A dramatic rise in respiration and a decline of photosynthetic activity have been described for several plant species infected by oomycetes causing downy mildew (23). Effects on the transpiration rate, which is often associated with photosynthetic activity, have been assessed only rarely. Cruickshank and Rider (13) reported that infection of tobacco leaves by Peronospora tabacina results in a small increase in transpiration in the light and a doubling of transpiration in the dark in the presporulation phase. The onset of the postsporulation phase brought with it a decrease in transpiration, probably due to the blockage of stomatal pores by sporangiophores.

A negative correlation between transpiration rate and leaf temperature has been shown by Inoue et al. (24). An increase in leaf temperature due to restricted water supply of the shoot has been 
described for diseases caused by root rot or wilt pathogens $(10,39,45)$. Necrotrophic leaf pathogens like Pyrenophora spp. and Pseudomonas syringae as well as Phytophthora sojae in soybean and Tobacco mosaic virus (TMV) in tobacco and Arabidopsis $l s d 2$ mutant cause stomatal closure and consequently reduce transpiration of infected leaves and increase canopy temperature $(7,8,14,35,40,41)$. In contrast, foliar temperature of susceptible wheat was reduced by 0.2 to $1.0^{\circ} \mathrm{C}$ during early sporulation of Puccinia striiformis due to rust pustules rupturing the epidermis and preventing stomatal closure followed by a significant temperature increase only in later stages of rust development (47).

Remote sensing and digital image analysis are methods of data acquisition and interpretation of measurements of an object without physical contact between measuring device and object, so that the same object can be analyzed many times noninvasively and without damage $(25,42)$. All objects at ambient temperature emit far infrared (IR) light of about $10 \mu \mathrm{m}$ wavelength. Infrared scanning cameras with detectors sensitive in the 8 to $14 \mu \mathrm{m}$ wavelength band convert IR radiation into a visual pseudocolor image representing leaf temperature variation. In plant biology, IR thermography is used to schedule irrigation (19), monitor ice-nucleation in plants (49), screen for mutants with altered stomatal control (36), and assess plant-pathogen interactions by monitoring patterns of surface leaf temperature (8).

Imaging techniques intrinsically possess a high spatial resolution enabling the visualization of patterns and gradients in the variables investigated (9). However, spatial heterogeneity and chronology of changes in leaf temperature resulting from altered leaf transpiration have not been recorded for downy mildew-infected leaves. Methods measuring gas exchange directly are often compromised by the fact that only small areas of leaves are infected and are responding to growth of pathogens. The sensitivity advantage of digital measurements allowing reasonable spatial resolution is especially pronounced at low levels of tissue colonization.

The objectives of this study were to (i) visualize changes in cucumber leaf transpiration using digital IR thermography, (ii) investigate the effect of Pseudoperonospora cubensis on transpiration rate at different stages of pathogenesis, and (iii) evaluate whether thermography may be used for the differentiation of infected tissue and healthy leaf areas.

\section{MATERIALS AND METHODS}

Plant material. Cucumber (Cucumis sativus) seeds of cv. Vorgebirgstraube, susceptible to downy mildew, were germinated on moist paper at $25 / 20^{\circ} \mathrm{C}$ for 4 days. Uniformly sized germinated seeds were transplanted into pots (diameter $11 \mathrm{~cm}$ ) with a 3:1 mixture of organic soil (Klasmann-Deilmann $\mathrm{GmbH}$, GeesteGroß Hesepe, Germany) and sand. The seedlings were grown in a greenhouse at $25 / 20^{\circ} \mathrm{C}$ (day/night) with an $\mathrm{RH}$ of $70 \pm 10 \%$ and a 16-h photoperiod ( $>300 \mu \mathrm{mol} \mathrm{m} \mathrm{m}^{-2} \mathrm{~s}^{-1}$ ); plants were watered daily with tap water.

Pathogen. Pseudoperonospora cubensis was maintained on the first true leaves of cucumber cv. Vorgebirgstraube in the greenhouse under the conditions described previously. To induce sporulation, plants showing first symptoms of downy mildew were placed in a darkened moist chamber at $20^{\circ} \mathrm{C}$ and $100 \% \mathrm{RH}$ for $18 \mathrm{~h}$. Zoosporangia that formed were dislodged with a soft artist's brush into a solution of $0.01 \%$ Tween 20 in tap water. The concentration was adjusted to $5 \times 10^{5}$ or $1 \times 10^{5}$ zoosporangia per $\mathrm{ml}$ with a Fuchs-Rosenthal hemacytometer.

Inoculation. Depending on the objective of the experiment, different methods of inoculation were carried out. For an accurate monitoring of disease development and related thermal effects, the first true leaf was turned upside down and held in place with adhesive tape for 2 days after unfolding of the second leaves. Pseudoperonospora cubensis was applied by placing $5 \times 10^{4}$ zo- osporangia in a $0.1-\mathrm{ml}$ droplet on the lower leaf surface of the leaves.

For simultaneous recording of leaf temperature and transpiration rate of infected and noninfected tissue, $2 \mathrm{ml}$ of the zoosporangia suspension containing $1 \times 10^{5}$ zoosporangia per $\mathrm{ml}$ was sprayed on the right half of the lower leaf surface of the first true leaves with a hand sprayer. Contact between the zoosporangia suspension and the left side of the leaf surface was prevented by an absorbent paper covering the left side of the leaf while spraying.

To study the development of the maximum temperature difference (MTD) within inoculated leaves, $5 \times 10^{5}$ zoosporangia was applied on the total lower leaf surface of first true leaves by spraying $5 \mathrm{ml}$ of a suspension containing $1 \times 10^{5}$ zoosporangia per $\mathrm{ml}$ with a hand sprayer.

Incubation. Immediately after inoculation, plants were placed in a moist chamber at $25^{\circ} \mathrm{C}$ under natural light conditions for $6 \mathrm{~h}$ in order to provide optimum infection conditions. As controls, noninoculated plants of the same age were sprayed with water and kept under the same conditions. Subsequently, inoculated plants and control plants were kept in the greenhouse under the conditions described previously.

Disease assessment. Inoculated plants were assessed daily for downy mildew development. At the first visible symptom, disease severity was assessed by visual rating of the percentage of leaf area showing characteristic symptoms. The necrotic area as well as the yellowish halo and the faded area surrounding the lesions were all included in the assessment of disease severity. Plants were scored on a scale of $0,1,3,5,10,20, \ldots 90$, and $100 \%$ of leaf area covered with symptoms.

Thermographic measurements, data acquisition, and analysis. Plants were equilibrated in the laboratory for $1 \mathrm{~h}$ before thermal images were recorded between 9 and 10 a.m. Air temperature in the laboratory was $25 \pm 1^{\circ} \mathrm{C}, \mathrm{RH}$ varied between 35 and $45 \%$, and photosynthetically active radiation was about $250 \mu \mathrm{mol} \mathrm{m} \mathrm{m}^{-2} \mathrm{~s}^{-1}$ for all measurements. Digital thermal images were obtained using a VARIOSCAN 3201 ST (Jenoptic Laser, Jena, Germany) sterling-cooled IR scanning camera with a spectral sensitivity ranging from 8 to $12 \mu \mathrm{m}$ and a geometric resolution of $1.5 \mathrm{mrad}(240 \times$ 360 pixels focal plane array and a $30^{\circ} \times 20^{\circ}$ field of view lens with a minimum focus distance of approximately $20 \mathrm{~cm}$ ). Thermal resolution was $0.03 \mathrm{~K}$, and accuracy of absolute temperature measurement was $< \pm 2 \mathrm{~K}$. Digital thermograms were analyzed with the software package IRBIS Plus version 2.2 (Infratec, Dresden, Germany), which allowed for correction of object emissivity after images had been recorded. However, leaf emissivity was set to 1 because relative differences in leaf temperature resulting from pathogen development were the main interest of these experiments. Despite being very different in optical terms, the emissivity of different tissues from various plants is very similar, ranging from 0.98 to 0.99 (1). For an air temperature of $25^{\circ} \mathrm{C}$, emissivity values of 0.98 or 0.99 would result in absolute temperature changes $<0.05 \mathrm{~K}$ and were therefore neglected.

Color pictures were taken with a digital camera (JD 4100 Z3, Jenoptic Laser). For accurate monitoring of disease development and related thermal effects, thermal and color reflectance images of leaves inoculated with 1 droplet on the lower leaf surface were taken and average temperature of healthy tissue and inoculated leaf areas were calculated 3, 5, and 7 days postinoculation (dpi).

For simultaneous recording of leaf temperature and transpiration rate of infected and noninfected tissue, thermal and color reflectance images of leaves inoculated on the right side were taken 3,4 , and 5 dpi. Subsequently, transpiration rate $(\mathrm{E}[\mathrm{mmol}$ $\left.\mathrm{H}_{2} \mathrm{O} \mathrm{m}^{-2} \mathrm{~s}^{-1}\right]$ ) and assimilation rate $\left(\mathrm{A}\left[\mu \mathrm{mol} \mathrm{CO}_{2} \mathrm{~m}^{-2} \mathrm{~s}^{-1}\right]\right)$ of inoculated and noninoculated tissue were measured for three areas $\left(2.5 \mathrm{~cm}^{2}\right)$ with a portable photosynthesis system with automated gas mixing and a Parkinson leaf chamber type PLC-B (CIRAS-1, PP Systems, Hitchin, UK). Flow rates were kept at 
$290 \mathrm{ml} / \mathrm{min}, \mathrm{CO}_{2}$ concentration was adjusted to $480 \mathrm{ppm}$, and photosynthetically active radiation was about $1,000 \mu \mathrm{mol} \mathrm{m} \mathrm{m}^{-2} \mathrm{~s}^{-1}$. The average leaf temperature measured with VARIOSCAN 3201 ST was calculated for the three areas representing the measuring areas for transpiration rate on the healthy and on the infected side of the leaves.

The MTD within healthy and infected leaves was studied by taking thermal and color reflectance images from control leaves and inoculated leaves and recording disease severity daily up to 6 days after inoculation. Using IRBIS Plus version 2.2, a polygon was placed on the area representing a leaf by redrawing the cucumber leaf's outline. For every polygon, MTD was automatically recorded as the difference between highest and lowest temperature within the polygon.

Stomatal aperture. The abaxial side of noninoculated and infected cucumber leaves showing chlorosis and necrosis was coated with transparent nail polish and peeled off with transparent tape. Epidermal imprints were placed on microscope slides and analyzed with a photomicroscope (Leitz DMRB; Leica, Wetzlar, Germany). The width of stomatal aperture was measured for 60 stomata each from noninoculated, chlorotic, and necrotic tissue using the software Diskus 4.2 (Hilgers, Königswinter, Germany) and averaged over three replicates.

Microscopy. Cucumber tissue $(1 \times 2 \mathrm{~mm})$ of uninfected and infected leaves at different stages of symptom development (oil spot, chlorosis, and necrosis) was fixed with $8 \%$ paraformaldehyde and $8 \%$ glutaraldehyde in $0.2 \mathrm{M}$ sodium cacodylate buffer $(\mathrm{pH} 7.3)$ under vacuum for $4 \mathrm{~h}$ at room temperature (29). The samples were washed three times in cacodylate buffer for $20 \mathrm{~min}$ each, dehydrated in a graded ethanol series, and embedded in London Resin white medium. The embedded material was semithin sectioned with a diamond knife on an ultra microtome (Reichert Ultracut E; Leica Microsystems, Nussloch, Germany) and was stained in $1 \%$ toluidine blue. Stained samples were observed with a Leitz DMRB photomicroscope and photographed with a digital camera.

Statistical analysis. All analyses were conducted using SPSS 11.0 (SPSS Inc., Chicago, IL). Data were analyzed by standard analysis of variance. When the $F$ values were significant, mean comparisons were performed with the least significant difference value at the least significance level of $P=0.05$. All experiments were conducted at least twice.

\section{RESULTS}

Temperature of cucumber leaves after spot inoculation with Pseudoperonospora cubensis. The lower surface of cucumber leaves was inoculated with 1 drop of Pseudoperonospora cubensis zoosporangia per leaf. Under the experimental conditions, irregular yellowish green areas on the upper leaf surface appeared as first characteristic symptoms of downy mildew 4 dpi. An initial thermal response of cucumber leaf tissue to Pseudoperonospora cubensis infection was observed at the inoculation sites 3 dpi. Leaf areas developing symptoms of downy mildew in later stages of pathogen development exhibited a temperature up to $0.8^{\circ} \mathrm{C}$ lower than the surrounding noninfected plant tissue (Fig. 1A). During the development of the first visible chlorosis at infection sites, leaf temperature remained about $0.8^{\circ} \mathrm{C}$ below that of healthy leaf areas. Between days 3 and 5 after inoculation, the size of the colder leaf areas detected by thermography increased in a similar pattern as the chlorotic spots expanded into adjacent leaf areas (Fig. 1B). With further development of downy mildew and expansion of the pathogen in the leaf, chlorosis became necrotic, beginning at the infection sites in the center of the chlorotic spots, while the periphery was still yellowish green. Simultaneously with necrotization, the temperature of affected tissue increased significantly and exceeded the temperature of noninfected leaf areas by up to $1^{\circ} \mathrm{C}$ (Fig. $1 \mathrm{~B}$ and $\mathrm{C}$ ). The temperature of leaf areas with necrotic cell death constantly remained higher than the temperature of healthy leaf tissue. Figure 2 depicts the reaction of cucumber tissue during different stages of downy mildew development in microscopic sections of primary infection sites (centers of necrotic lesions). Water-soaked lesions developed 2 days after inoculation with turgescent cells and intercellular hyphae of Pseudoperonospora cubensis in the mesophyll; cells of palisade parenchyma were modified and the number of chloroplasts was reduced considerably (Fig. 2B). The formation of chlorosis was associated with disintegration of mesophyll cells and abundant hyphal growth (Fig. 2C) and resulted in the necrotization of leaf tissue characterized by collapsed epidermal and mesophyll cells; hyphae within necroses were hardly detectable at this stage (Fig. 2D).

Correlation between temperature and transpiration of cucumber leaves infected with Pseudoperonospora cubensis. In these experiments, the right half of the leaves were spray-inoculated with Pseudoperonospora cubensis. Three days after inoculation, $40 \%$ of inoculated leaf sides showed yellowish green chlorosis on the upper leaf surface; no symptoms were observed on the noninoculated sides of the leaves. The chlorotic spots expanded, and at $4 \mathrm{dpi}, 80 \%$ of the inoculated side had become chlorotic. One day later these leaf areas turned necrotic while the surrounding areas became chlorotic; finally, almost the total area of the inoculated leaf sides had become necrotic. Under these experimental conditions, sporulation of Pseudoperonospora cubensis was not observed.

Leaf temperature. Three days after inoculation, infected cucumber tissue was $0.8^{\circ} \mathrm{C}$ colder than the noninoculated leaf side. Leaf temperature further decreased during downy mildew development, and at $4 \mathrm{dpi}$, leaf temperature of inoculated sides was $1.8^{\circ} \mathrm{C}$ lower than the healthy leaf area. With the necrotization and the subsequent desiccation of dead tissue, the temperature of diseased sides of cucumber leaves increased above the level of healthy leaf tissue (Fig. 3). Five days after inoculation, the difference between infected and unaffected tissue was $0.7^{\circ} \mathrm{C}$ (Fig. 3).

Transpiration rate. Three and four days after inoculation, the transpiration rate of infected tissue was about $0.5 \mathrm{mmol} \mathrm{m} \mathrm{m}^{-2} \mathrm{~s}^{-1}$ $(=35 \%)$ higher than that of the healthy tissue on the other side of

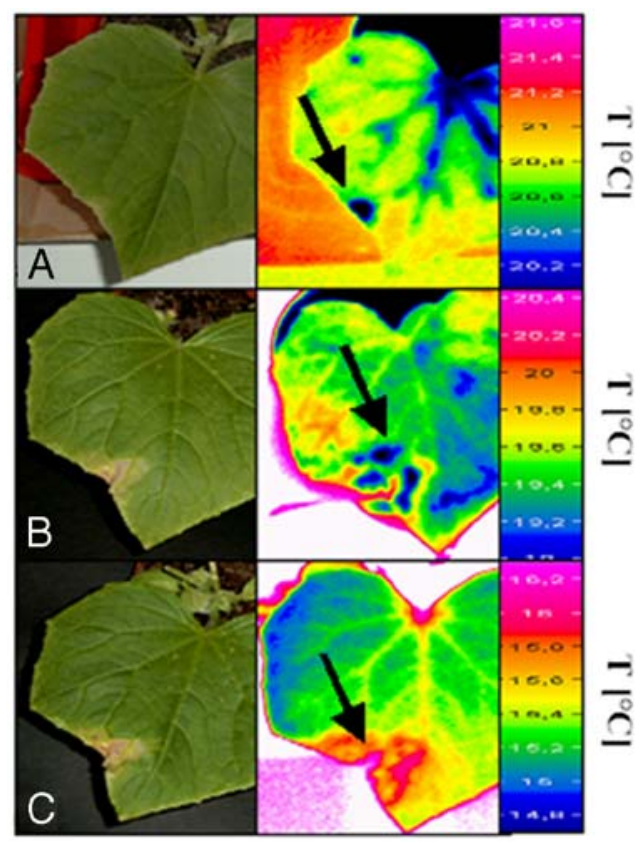

Fig. 1. Dynamics of temperature of cucumber leaves inoculated with Pseudoperonospora cubensis. Digital color reflectance (left) and thermal (right) images from the same leaf at $\mathbf{A}, 3 ; \mathbf{B}, 5$; and $\mathbf{C}, 7$ days after spot inoculation on the lower side of the leaf (arrow). 
the leaves. It decreased subsequently, and at 5 dpi, the transpiration rate of the diseased side of the leaves was $0.8 \mathrm{mmol} \mathrm{m}^{-2} \mathrm{~s}^{-1}$ $(55 \%)$ lower than the transpiration of the noninoculated side (Fig. $3)$. The temperature of cucumber leaf tissue was negatively correlated with transpiration rate $(r=-0.762, P<0.001, n=18)$ (Fig. 4).

Measurements of stomatal opening of noninfected, chlorotic, and necrotic leaf tissue revealed significant differences (Fig. 5). Chlorotic cucumber tissue around infection sites had a markedly greater stomatal aperture than the adjacent healthy areas. After cell death and necrotization, the average aperture of stomata was still greater than that of the healthy tissue, but significantly smaller than that of chlorotic tissue.

Photosynthetic $\mathrm{CO}_{2}$ assimilation. During the experimental period, net photosynthetic rate of healthy leaf areas decreased slightly from $17\left( \pm 1.4\right.$ standard deviation) $\mu \mathrm{mol} \mathrm{m} \mathrm{m}^{-2} \mathrm{~s}^{-1}$ to $16( \pm 1.5)$ and $12( \pm 0.8) \mu \mathrm{mol} \mathrm{m} \mathrm{m}^{-2} \mathrm{~s}^{-1}$ at 4 and $5 \mathrm{dpi}$, respectively. The development of downy mildew decreased net photosynthetic rate to $5( \pm 0.8) \mu \mathrm{mol} \mathrm{m} \mathrm{m}^{-2} \mathrm{~s}^{-1}$ at $3 \mathrm{dpi}$; at $4 \mathrm{dpi}$, the gross photosynthesis equaled respiration rate and net photosynthesis was $0( \pm 0.6) \mu \mathrm{mol} \mathrm{m} \mathrm{m}^{-2} \mathrm{~s}^{-1}$. Subsequently, at $5 \mathrm{dpi}$, when parts of the leaf tissue had become necrotic, the net photosynthetic rate of diseased leaf areas was negative and the respiration rate exceeded the net assimilation rate by $1( \pm 0.1) \mu \mathrm{mol} \mathrm{m} \mathrm{m}^{-2} \mathrm{~s}^{-1}$.

Temperature of cucumber leaves after spray inoculation with Pseudoperonospora cubensis. Pseudoperonospora cubensis caused first yellow leaf spots at 4 dpi (45\% leaf area), which expanded to 75 and $95 \%$ of leaf area at 5 and 6 dpi, respectively (Fig. 6). Necrotization of infected leaves started at 5 dpi and reached almost $75 \%$ of leaf area at $6 \mathrm{dpi}$.

Leaf temperature of noninoculated leaves was almost constant during the experiment; leaf margins exhibited a higher temperature than the leaf lamina with intercostal leaf areas showing the lowest temperature. The temperature distribution remained homogenous, and MTD between maximum and minimum temperature of total leaf areas was $<0.9^{\circ} \mathrm{C}$ (Fig. 6). The temperature distribution was still undistinguishable from that of noninoculated leaves at $1 \mathrm{dpi}$; however, at $2 \mathrm{dpi}$, MTD of infected leaves was significantly higher $\left(+0.6^{\circ} \mathrm{C}\right)$ than that of healthy leaves. With the development of downy mildew symptoms, MTD increased by more than $2.0^{\circ} \mathrm{C}$ at 5 and $6 \mathrm{dpi}$, about $1.4^{\circ} \mathrm{C}$ higher than for noninoculated control leaves (Fig. 7). The slight decrease in MTD at 6 dpi coincided with an almost total destruction of leaf tissue by Pseudoperonospora cubensis.

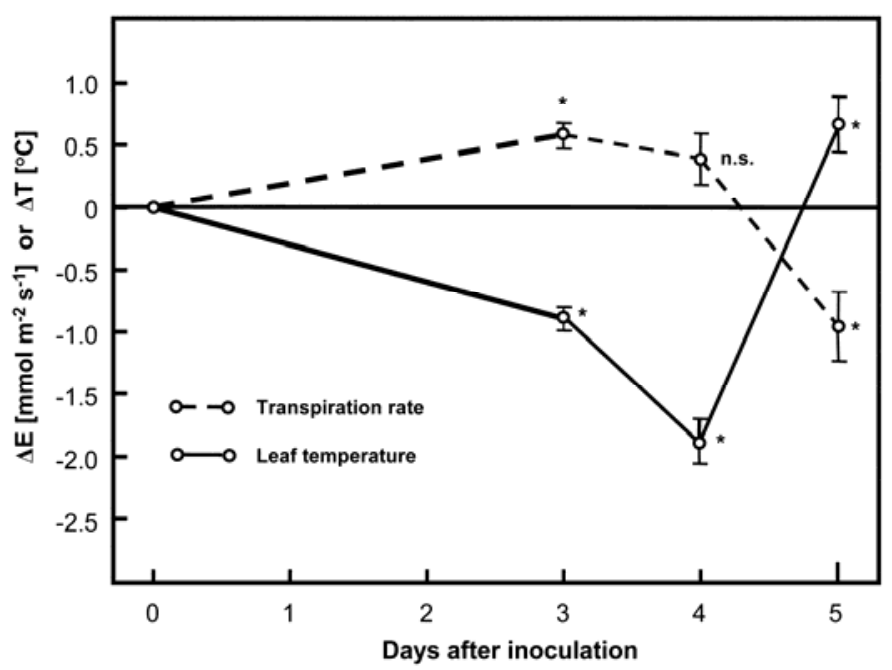

Fig. 3. Effect of Pseudoperonospora cubensis infection on leaf temperature and transpiration rate of cucumber leaves during pathogenesis. Temperature, measured thermographically, and transpiration rate, measured with a portable photosynthesis system, are given as differences $(\Delta \mathrm{T}, \Delta \mathrm{E})$ between healthy and infected tissue. Asterisks indicate values of $\Delta \mathrm{T}$ and $\Delta \mathrm{E}$ significantly different from $0(t$ test, $P<0.05, n=9)$. Error bars indicate standard deviations.
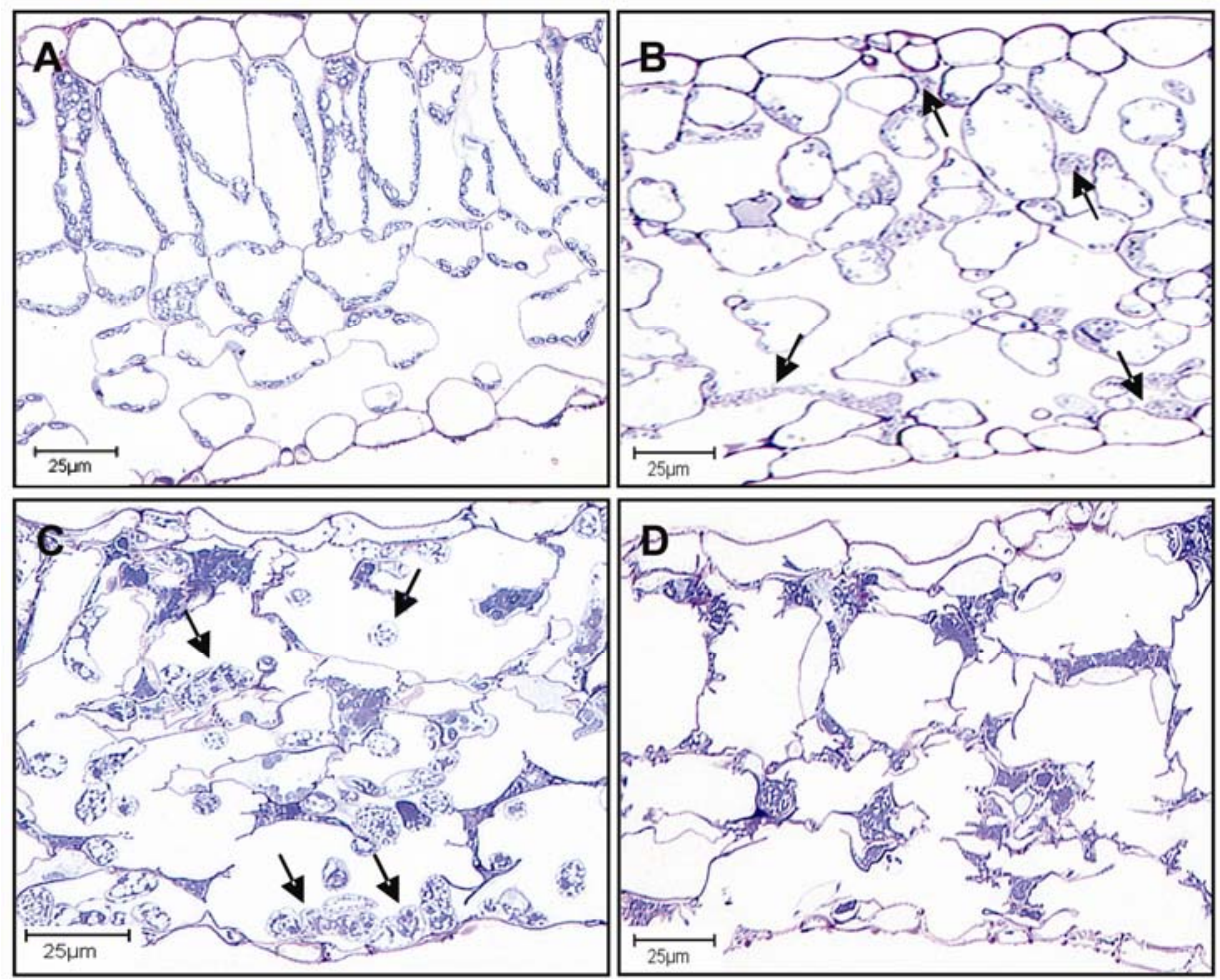

Fig. 2. Sections of cucumber leaf tissue infected with Pseudoperonospora cubensis during different stages of pathogen development: A, healthy tissue; B, tissue without macroscopical symptoms but with intercellular hyphae in the mesophyll layer, cells of palisade parenchyma modified, and number of chloroplast reduced considerably; C, chlorotic tissue with hyphae of Pseudoperonospora cubensis; and $\mathbf{D}$, necrotic tissue at the infection site 5 days after inoculation. Arrows indicate hyphae of Pseudoperonospora cubensis; leaf transections are stained with toluidine blue. 


\section{DISCUSSION}

It is well known from energy balance considerations that temperature of healthy leaves varies with leaf transpiration and, therefore, is a function of stomatal conductance $(18,26,27)$. Inoue et al. (24) reported a negative linear correlation between transpiration rate and leaf temperature, which was confirmed in this study. Stomatal conductance is mainly influenced by abiotic factors such as water status and solar radiation but may also be affected by foliar pathogens which infect plants by penetrating stomata and/or increase water permeability of cell membranes by producing toxins or lytic enzymes $(20,31)$. Moreover, when producing visible disease symptoms, pathogens transiently or permanently enhance water loss by increasing the evaporating surface through the development of infection structures on the plant surface, by damaging the plant cuticle, and by causing cell death resulting in uncontrolled water loss (5).

In the cucumber-downy mildew interaction, the decrease in temperature of infected leaf areas at early stages of pathogenesis was directly related to an increase in transpiration rate. Many pathogens cause an increase in the transpiration rate of leaves because any pathogen that damages the surface layers of the leaf will increase cuticular transpiration resulting in an increased rate of water loss (31). The chromista causing downy mildews, however, are obligate biotrophic pathogens. After infection through stomata, they grow intercellularly and form haustoria by invaginating the plasma membrane of living cells (48) without producing toxins and with limited production of extracellular cell wall-degrading enzymes (37). Damage of host tissue is therefore minimal during early stages of host-pathogen interaction (30). Nevertheless, on leaf areas inoculated with zoosporangia of Pseudoperonospora cubensis, cold spots appeared 1 day before visual symptoms. The failure to observe morphological damage of the host tissue in microscopic analysis strongly suggests that the increased stomatal opening at infection sites is caused by physiological factors during early stages of pathogenesis. This is in agreement with results of increased transpiration of potato leaves at infection sites of Phytophthora infestans (16). Similarly, barley plants infected by the necrotrophic fungus Rhynchosporium secalis had an increased proportion of open stomata in the dark (4).

Infections by the obligate biotrophic fungi causing rust or powdery mildew result in an inhibition of stomatal opening in the light. In rust-infected leaves, stomatal aperture eventually remains

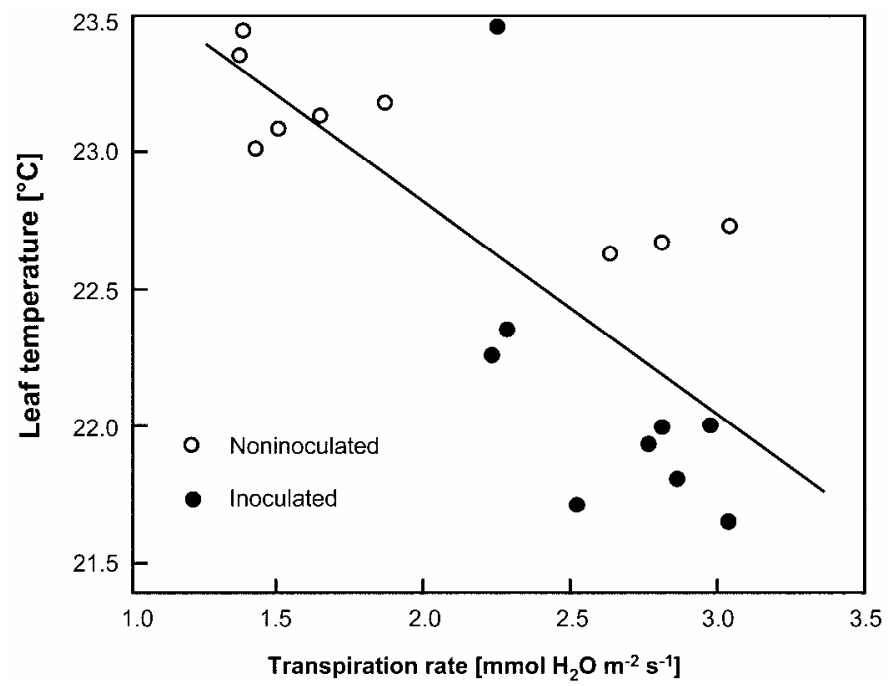

Fig. 4. Correlation between leaf temperature measured thermographically and transpiration rate measured with a portable photosynthesis system of cucumber leaves infected with Pseudoperonospora cubensis. Data represent measurements 3 days after inoculation $(r=-0.762, P<0.001$, $n=18)$. smaller (15), and once fungal sporulation has ruptured the cuticle, stomatal resistance ceases to be the primary factor determining whole leaf resistance, because cuticular resistance is much reduced. Powdery mildew infection results in the inability of stomata to open in the light and to close in the dark $(2,32)$. Stomata may eventually remain in a partially open state (3). Stomatal opening and transpiration may be inhibited in the wheat-powdery mildew system within $6 \mathrm{~h}$ of inoculation (34), and it was suggested that a volatile product of fungal metabolism was involved. After development of fungal signs, the pathogens also contribute to an increased evaporation.

Infection of potato by the late blight pathogen Phytophthora infestans induced stomata to open more widely than normal in the light and not too close in the dark, resulting in increased transpiration (16). Infection results in the accumulation of soluble sugars contributing to an increase of the osmotic potential. Water loss from leaky mesophyll cells and increases in the osmotic potential of guard cells linked to stomatal opening may result in higher stomatal conductance and may also contribute to an increase of $\mathrm{CO}_{2}$ fixation in the area surrounding necrosis. Farrell et al. (16) reported a similarity in the positions of open stomata and increased photosynthesis for potato leaves infected with Phytophthora infestans. For the necrotrophic fungus Fusicoccum amygdali attacking peach and almond, fusicoccin, a non-host-specific toxin, is reported to immobilize stomata in an open position by affecting ion transport across guard cell membranes. The toxin stimulates the $\mathrm{K}^{+}{ }_{\text {in }} / \mathrm{H}^{+}{ }_{\text {out }}$ exchange that is a normal part of solute accumulation and turgor development as guard cells open in response to illumination (33). In harpin-induced hypersensitive reaction of Nicotiana sylvestris, the stomatal opening-associated decrease in temperature preceded necrosis symptoms for several hours (6). The temperature of water-soaked leaf areas was transiently $2^{\circ} \mathrm{C}$ lower than that of water-infiltrated control leaves; however, data on leaf temperature during the formation of necrosis were not given.

Changes in the permeability of plasma membranes are reported to be among the first host reactions to fungal infection (31). Enhanced $\mathrm{Ca}^{2+}$ influx as the earliest measurable effect of Blumeria graminis on barley activates anion channels or deactivates the plasma membrane $\mathrm{H}^{+}$ATPase, resulting in the depolarizing of inorganic anions, leakage of organic anions, and the alkalinization of the apoplast about 2-h postinoculation (17). Changes in the semipermeable properties of plasma membranes are associated

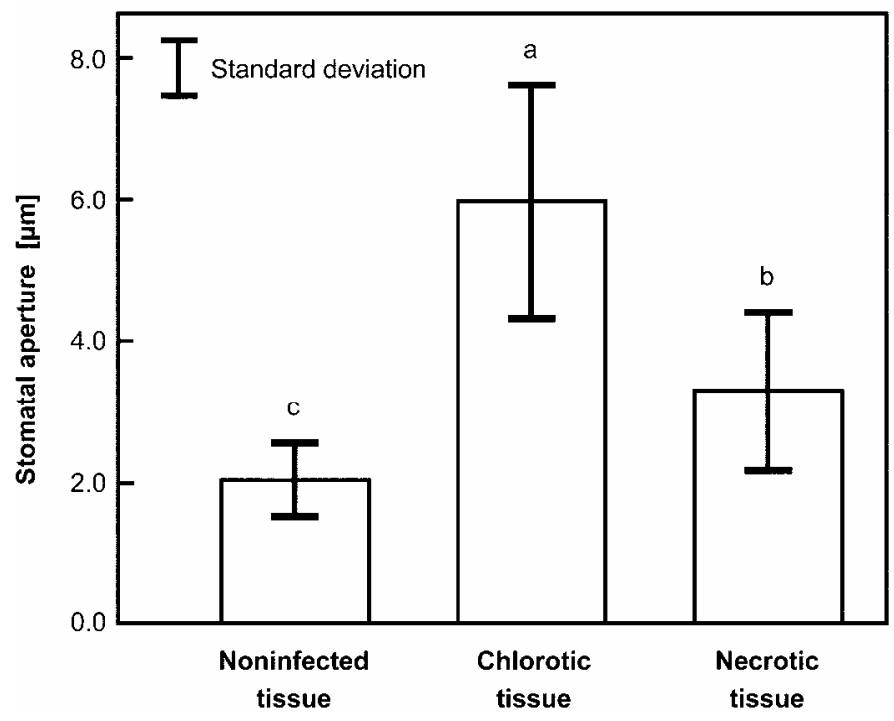

Fig. 5. Opening of stomata of the abaxial epidermis of cucumber leaves infected with Pseudoperonospora cubensis. Measurements of stomata are from leaves illuminated for $9 \mathrm{~h}$. Bars with the same letters are not significantly different (Tukey test, $P<0.05, n=60$ ). 
with a definite increase in the leakage of electrolytes from diseased tissue and are related to the uptake of nutrients by the pathogen (31). Infections by obligate fungal parasites often cause the accumulation of metabolites at infection sites which induce abnormal phloem transport of nutrients (20). Lesions caused by Pseudoperonospora cubensis are strong sinks for nutrients (48). After placing plants labeled with ${ }^{14} \mathrm{CO}_{2}$ in a moist chamber in darkness, there was a massive transfer of radioactivity from both diseased and healthy tissues into the developing sporangia of Pseudoperonospora cubensis $(21,22,44)$. High-molecular-weight carbohydrates were hydrolyzed to hexose-like materials to be transferred into the pathogen. Enhanced transpiration of infected tissue due to loss of integrity of cell membranes may also lead to an increase of xylem transport toward infection sites in order to adjust imbalances in water status and to abide the turgor of mesophyll cells resulting in abnormal stomatal opening. Increased xylem transport toward the site of infection results in a larger amount of water per unit of leaf area and a higher water potential of the tissue which may affect the regulation of stomatal aperture. Stomatal opening did not result from the formation of sporangia through stomata because, at that time, the latent period of the pathogen was not complete and sporulation of Pseudoperonospora cubensis was not observed under the experimental conditions.

With the subsequent spread of Pseudoperonospora cubensis hyphae into neighboring mesophyll, adjacent cells also became affected and the cooling effect from increased transpiration increased in area and intensity. A front of decreased temperature expanded toward healthy tissue similar to the thermal sequence reported for the hypersensitive reaction of tobacco leaves to TMV infection (7). The loss of membrane integrity was associated with increased water loss due to abnormal stomatal opening as demonstrated by the increased stomatal aperture of chlorotic tissue. In the hypersensitive reaction of tobacco and Arabidopsis $l s d 2$ mutant, an initial rise in leaf temperature due to stomatal closure was followed by increased water evaporation of damaged cells, a short-term effect (about 4 to $6 \mathrm{~h}$ ) associated with the programmed death of infected cells limited to infection sites. Salicylic acid is reported to cause the closure of stomata (8). In contrast, the thermal sequence reported for the compatible host-pathogen system cucumber-Pseudoperonospora cubensis occurred before the death of damaged tissue and expanded simultaneously with the spread of the pathogen into the neighboring leaf areas. The effect of downy mildew on leaf temperature and transpiration rate of healthy tissue on the other side of the midrib was small, and the difference in leaf temperature and transpiration between healthy leaves and the healthy side of inoculated leaves was not significant (data not shown).

With the appearance of necrotic cell death, the temperature of affected tissue increased well above the temperature level of noninfected tissue. Increased water loss of tissue and the inability

\section{noninoculated}

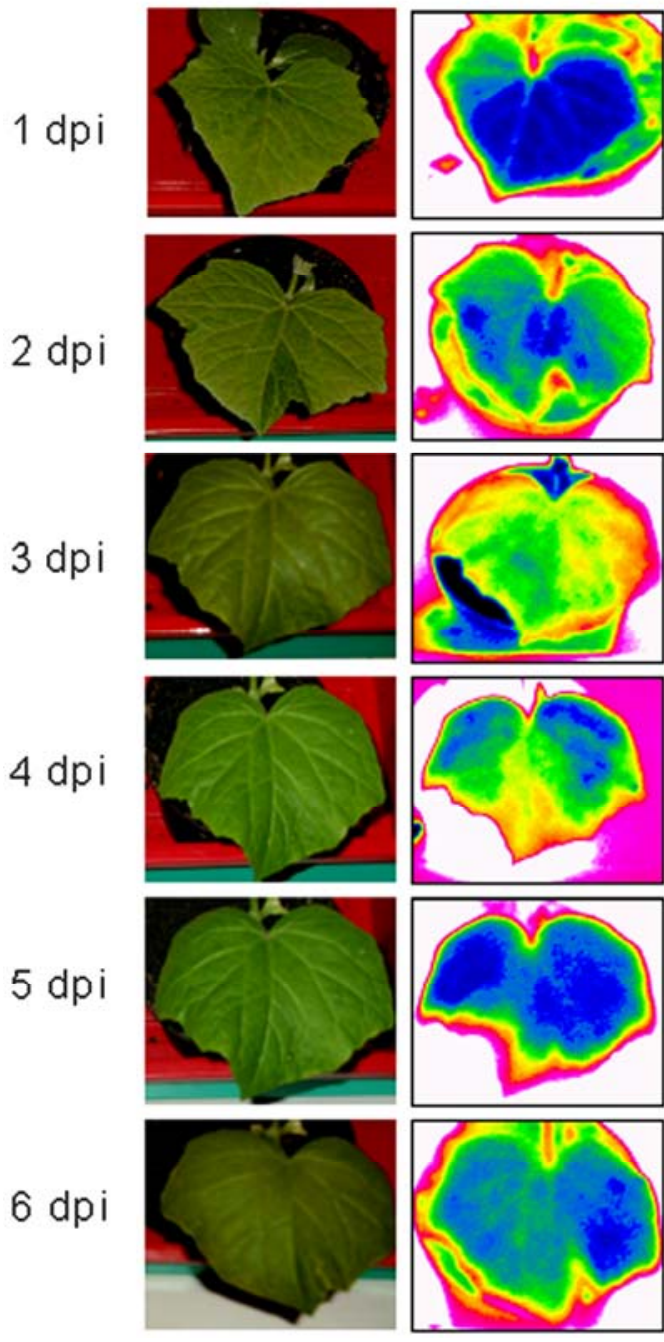

inoculated

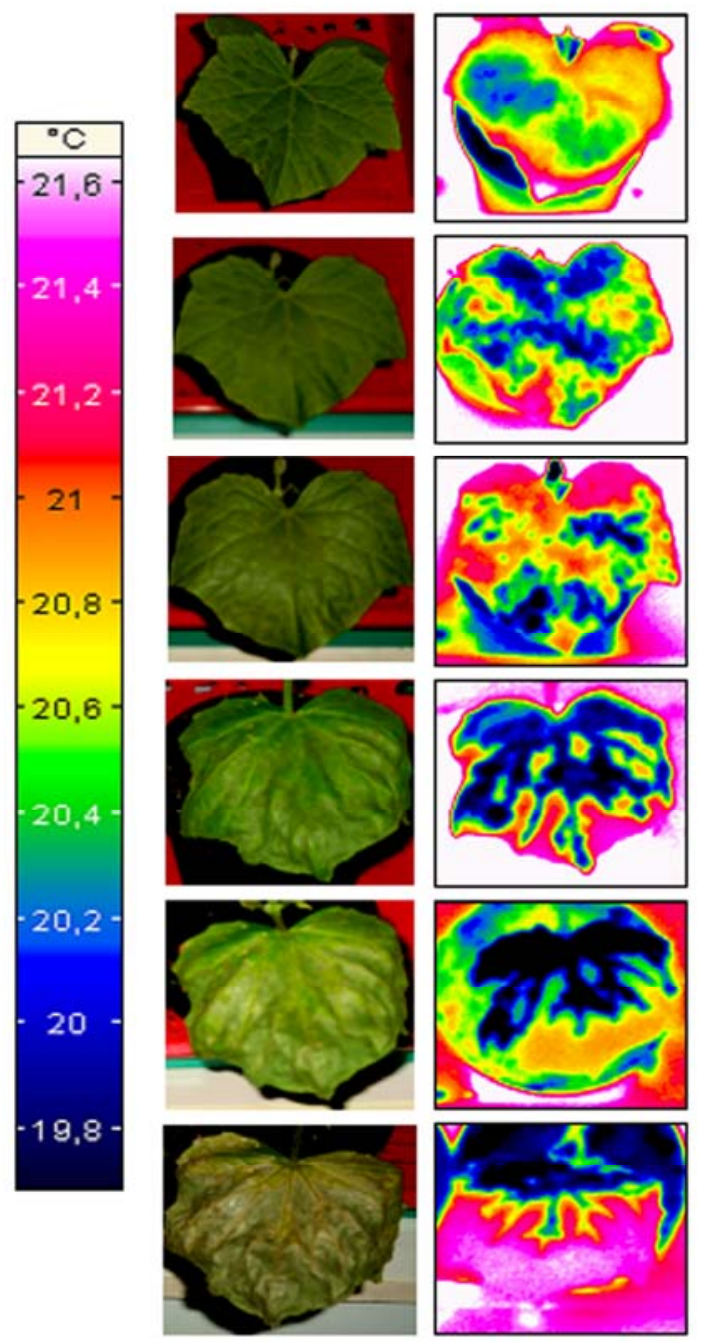

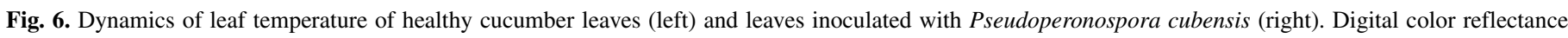
and thermal images are given for six successive days after spray inoculation of leaves. 
of plant tissue to regulate stomatal opening promoted cell death. Similarly, transpiration of beans was significantly reduced by angular leaf spot due to Phaeoisariopsis griseola and anthracnose due to Colletotrichum lindemuthianum starting with symptom appearance, whereas leaf rust due to the obligate pathogen Uromyces appendiculatus hardly affected transpiration (5). Infection with Blumeriella jaapi, the causal agent of cherry leaf spot, reduces net photosynthesis and transpiration during all stages of disease development, even before visible symptoms occur on cherry leaves (38). Desiccation and the lack of natural cooling from transpiration resulted in a considerable increase of temperature at the primary infection sites of Pseudoperonospora cubensis. Therefore, leaf areas with progressing downy mildew were typically characterized by a pattern of distinct temperature zones corresponding to different stages of disease development: high temperature associated with necrotic tissue in the center surrounded by a zone of decreased leaf temperature associated with chlorotic tissue and symptomless infected tissue. Often, a transient zone with normal leaf temperature could be detected between these rings.

The increase in transpiration after infection is believed to be involved in the redirection or accumulation of nutrients, inducing a transpiration sink (46). With downy mildew, however, evaporation from necrotic tissue was low. Only vital leaf areas harboring the growing pathogen showed an increased sink activity as indicated by the higher transpiration rate. Lesions produced by necrotrophs, therefore, are unlikely to be involved in the formation of a transpiration sink for the redirection of nutrients in the interactions of plants with necrotrophic pathogens as discussed by Schlösser (46).

The development of downy mildew was associated with localized transient decreases and subsequent increases in leaf temperature. Typical spots of lower or higher temperature at infection sites resulted in an increased heterogeneity of temperature distribution of infected leaves. The MTD proved to be a suitable parameter for the discrimination between healthy and infected leaves before the appearance of visible symptoms. The temperature extremes of healthy leaves remained uniform during the experiments, with a maximal difference of less than $1^{\circ} \mathrm{C}$. For leaves inoculated with Pseudoperonospora cubensis, MTD increased as early as 2 days after inoculation, indicating a patchiness of temperature distribution. With disease levels reaching $100 \%$ leaf area,

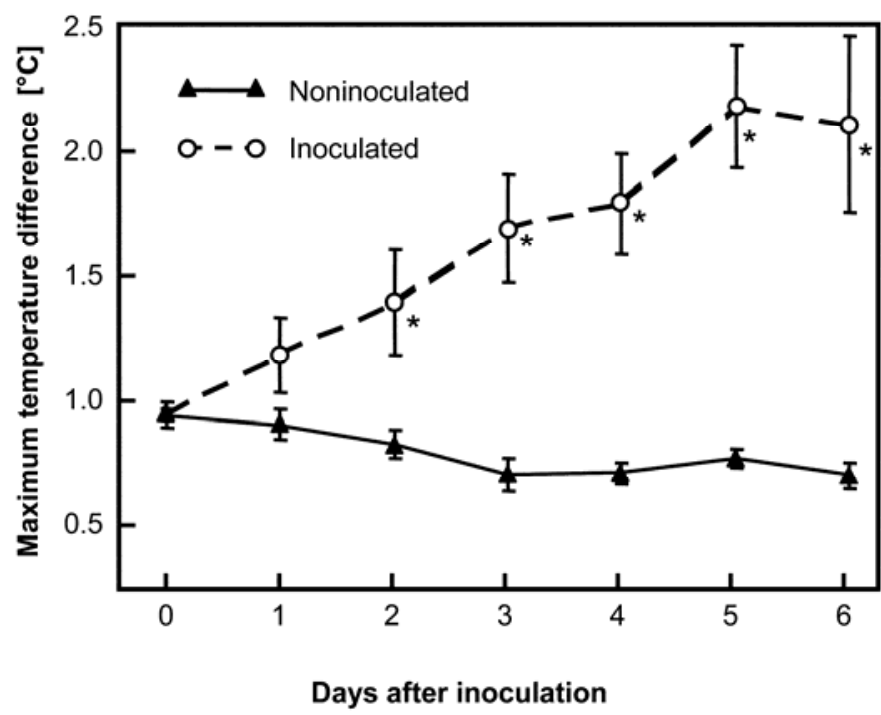

Fig. 7. Effect of Pseudoperonospora cubensis infection on maximum temperature difference, the difference between highest and lowest temperature within a thermogram of a spray-inoculated cucumber leaf. Asterisks indicate means that differ significantly ( $t$ test, $P<0.05, n=5$ ). Error bars indicate standard deviations.
MTD decreased at the end of the experiments because nearly all leaf area became uniformly necrotic, resulting in high leaf temperature.

Using MTD for the interpretation of thermal images seems to be easier than using a reference leaf or surface temperature as suggested by Jones et al. (28). Absolute leaf temperatures may vary considerably in response to environmental factors, including air temperature, solar radiation, and air turbulence, and in response to the physiological status of the plant resulting from water potential, leaf age, and microhabitat. MTD of leaves may be used for the detection of host-pathogen interactions causing spatial and temporal heterogeneity in plant transpiration and evaporation. Due to the rather unspecific reaction of transpiration to different stressors, the method does not allow the identification or differentiation of the causal agent(s). However, characteristic spatial (and temporal) patterns of leaf temperature may be suitable for remote sensing approaches; their potential in practical crop protection has to be elucidated in more detail.

Digital thermography is an interesting tool in biological research because this remote sensing technique interferes as little as possible with the plant and its environment. Leaf temperature is measured without physical contact with the object and the noninvasive method allows the recording of time series experiments and an indirect visualization of spatial and temporal changes in transpiration rate. Thermograms may be produced with high spatial and temporal resolution, enabling their use in short-term and long-term experiments on leaf transpiration. Spatial resolution of thermography results in more specific information on plants' transpiration as affected by foliar pathogens, especially for early stages of pathogenesis when the portion of affected tissue is small.

\section{ACKNOWLEDGMENTS}

This study was performed within the university graduate training program "Use of information systems for precision plant protection in agriculture and horticulture" from the Faculty of Agricultural Sciences at the Rheinische Friedrich-Wilhelms-University of Bonn funded by the German Research Foundation (DFG).

\section{LITERATURE CITED}

1. Accetta, J. S., and Shumaker, D. L. 1993. The Infrared and ElectroOptical Systems Handbook. SPIE Optical Engineering Press, Washington, D.C.

2. Ayres, P. G. 1976. Patterns of stomatal behaviour, transpiration and $\mathrm{CO}_{2}$ exchange in pea following infection by powdery mildew (Erysiphe pisi). J. Exp. Bot. 27:354-363.

3. Ayres, P. G. 1978. Water relations in diseased plants. Pages 1-60 in: Water Deficits and Plant Growth, Vol. 5. T. T. Kozlowski, ed. Academic Press, London.

4. Ayres, P. G., and Jones, P. 1975. Increased transpiration and the accumulation of root absorbed $86 \mathrm{Rb}$ in barley leaves infected by Rhynchosporium secalis (leaf blotch). Physiol. Plant Pathol. 7:49-58.

5. Bassanezi, R. B., Amorim, L., Bergamin Filho, A., and Berger, R. D. 2002. Gas exchange and emission of chlorophyll fluorescence during the monocycle of rust, angular leaf spot and anthracnose on bean leaves as a function of their trophic characteristics. J. Phytopathol. 150:37-47.

6. Boccara, M., Boué, C., Garmier, M., De Paepe, R., and Boccara, A. C. 2001. Infra-red thermography revealed a role for mitochondria in presymptomatic cooling during harpin-induced hypersensitive response. Plant J. 28:663-670.

7. Chaerle, L., de Boever, F., van Montagu, M., and van der Straeten, D. 2001. Thermographic visualization of cell death in tobacco and Arabidopsis. Plant Cell Environ. 24:15-25.

8. Chaerle, L., van Caeneghem, W., Messens, E., Lambers, H., van Montagu, M., and van der Straeten, D. 1999. Presymptomatic visualization of plantvirus interactions by thermography. Nat. Biotech. 17:813-816.

9. Chaerle, L., and van der Straeten, D. 2000. Imaging techniques and the early detection of plant stress. Trends Plant Sci. 5:495-501.

10. Chaerle, L., and van der Straeten, D. 2001. Seeing is believing: Imaging techniques to monitor plant health. Biochim. Biophys. Acta 1519:153-166 
11. Cohen, Y. 1977. The combined effects of temperature, leaf wetness and inoculum concentration on infection of cucumbers with Pseudoperonospora cubensis. Can. J. Bot. 55:1487.

12. Cohen, Y., Perl, M., and Rotem, J. 1971. The effect of darkness and moisture on sporulation of Pseudoperonospora cubensis in cucumbers. Phytopathology 61:594-595.

13. Cruickshank, I. A. M., and Rider, N. E. 1961. Peronospora tabacina on tobacco: Transpiration, growth and related energy considerations. Aust. J. Biol. Sci. 14:45-57.

14. Di Giorgio, D., Camoni, L., Mott, K. A., Takemoto, J. Y., and Ballio, A. 1996. Syringopeptins, Pseudomonas syringae pv. syringae phytotoxins, resemble syringomycin in closing stomata. Plant Pathol. 45:564-571.

15. Duniway, J. M., and Durbin, R. D. 1971. Detrimental effect of rust infection on the water relations of bean. Plant Physiol. 48:69-72.

16. Farrell, G. M., Preece, T. F., and Wren, M. 1969. Effects of infection by Phytophthora infestans (Mont.) de Bary on the stomata of potato leaves. Ann. Appl. Biol. 63:265-275.

17. Felle, H. H., Herrmann, A., Hanstein, S., Hückelhoven, R., and Kogel, K. H. 2004. Apoplastic $\mathrm{pH}$ signaling in barley leaves attacked by the powdery mildew fungus Blumeria graminis f. sp. hordei. Mol. PlantMicrobe Interact. 17:118-123.

18. Fuchs, M., and Tanner, C. B. 1966. Infrared thermometry of vegetation. Agron. J. 58:597-601.

19. Gebhardt, A. 1990. Differenzierte Einschätzung des Wasserversorgungszustandes landwirtschaftlicher Kulturen mittels thermografischer Luftaufnahmen. Arch. Acker-Pflanzenbau Bodenkd. 34:741-748.

20. Goodman, R. N., Kiraly, Z., and Wood, K. R. 1986. The Biochemistry and Physiology of Plant Disease. University of Missouri Press, Columbia.

21. Inaba, T., and Kajiwara, T. 1974. Fixation of ${ }^{14} \mathrm{CO}_{2}$ in the dark by cucumber leaf infected with the cucumber downy mildew fungus. Ann. Phytopathol. Soc. Jpn. 40:295-298.

22. Inaba, T., and Kajiwara, T. 1975. Physiological studies of cucumber downy mildew disease, with special reference to the relationship between lesion development, sporulability in lesions, and photosynthesis of host cucumber leaves. Bull. Natl. Inst. Agric. Sci. C 29:65-139.

23. Ingram, D. S. 1981. Physiology and biochemistry of host-parasite interaction. Pages 143-163 in: The Downy Mildews. D. M. Spencer, ed. Academic Press, London.

24. Inoue, Y., Kimball, B. A., Jackson, R. D., Pinter, P. J., and Reginato, R. J. 1990. Remote estimation of leaf transpiration rate and stomatal resistance based on infrared thermometry. Agric. For. Meteorol. 51:21-33.

25. Jackson, H. D. 1986. Remote sensing of biotic and abiotic plant stress. Annu. Rev. Phytopathol. 24:265-287.

26. Jones, H. G. 1992. Plant and Microclimate. 2nd ed. Cambridge University Press, Cambridge.

27. Jones, H. G. 1999. Use of thermography for quantitative studies of spatial and temporal variation of stomatal conductance over leaf surfaces. Plant Cell Environ. 22:1043-1045.

28. Jones, H. G., Stoll, M., Santos, T., De Sousa, C., Chaves, M. M., and Grant, O. M. 2002. Use of infrared thermography for monitoring stomatal closure in the field: Application to grapevine. J. Exp. Bot. 53:2249-2260.

29. Karnovsky, E. 1965. A formaldehyde glutaraldehyde fixative of osmolality for use in electron microscopy. J. Cell Biol. 27:137-138.

30. Lebeda, A., and Schwinn, F. J. 1994. The downy mildews-An overview of recent research progress. J. Plant Dis. Prot. 101:225-254.

31. Lucas, J. A. 1998. Plant Pathology and Plant Pathogens. Blackwell Science, Bristol.
32. Majernik, O. 1971. A physiological study of the effect of $\mathrm{SO}_{2}$ pollution, phenyl mercury acetate sprays, and parasitic infection on stomatal behaviour and ageing in barley. Phytopathol. Z. 72:255-268.

33. Marré, E. 1979. Fusicoccin: A tool in plant physiology. Annu. Rev. Plant Physiol. 30:273-288.

34. Martin, T. J., Stuckey, R. E., Safir, G. R., and Ellingboe, A. H. 1975. Reduction of transpiration from wheat caused by germinating conidia of Erysiphe graminis f. sp. tritici. Physiol. Plant Pathol. 7:71-77.

35. McDonald, K. L., and Cahill, D. M. 1999. Evidence for a transmissible factor that causes rapid stomatal closure in soybean at sites adjacent to and remote from hypersensitive cell death induced by Phytophthora sojae. Physiol. Mol. Plant Pathol. 55:197-203.

36. Merlot, S., Mustilli, A. C., Genty, B., North, H., Lefebvre, V., Sotta, B., Vavasseur, A., and Giraudat, J. 2002. Use of infrared thermal imaging to isolate Arabidopsis mutants defective in stomatal regulation. Plant $\mathbf{J}$. 30:601-609.

37. Michelmore, R. W., Ilott, T., Hulbert, S. H., and Farrara, B. 1988. The downy mildews. Pages 54-79 in: Advances in Plant Pathology. Vol. 6. Genetics of Plant Pathogenic Fungi. D. S. Ingram and P. H. Williams, eds. Academic Press, London.

38. Niederleitner, S., and Knoppik, D. 1997. Effects of the cherry leaf spot pathogen Blumeriella jaapi on gas exchange before and after expression of symptoms on cherry leaves. Physiol. Mol. Plant Pathol. 51:145-153

39. Nilsson, H. E. 1985. Remote sensing of oilseed rape infected by Sclerotinia stem rot and Verticillium wilt. Vaxtskyddsrapp. Jordbruk 33, Swed. Univ. Agric. Sci., Uppsala, Sweden.

40. Nilsson, H. E. 1985. Remote sensing of 6-row barley infected by barley stripe disease. Vaxtskyddsrapp. Jordbruk 36, Swed. Univ. Agric. Sci., Uppsala, Sweden.

41. Nilsson, H. E. 1985. Remote sensing of 2-row barley infected by net blotch disease. Vaxtskyddsrapp. Jordbruk 34, Swed. Univ. Agric. Sci., Uppsala, Sweden.

42. Nilsson, H. E. 1995. Remote sensing and image analysis in plant pathology. Annu. Rev. Phytopathol. 33:489-527.

43. Palti, J., and Cohen, Y. 1980. Downy mildew of cucurbits: The fungus and its hosts, distribution, epidemiology and control. Phytoparasitica 8:109147.

44. Perl, M., Cohen, Y., and Rotem, J. 1972. The effect of humidity during darkness on the transfer of assimilates from cucumber leaves to sporangia of Pseudoperonospora cubensis. Physiol. Plant Pathol. 2:113-122.

45. Pinter, P. J., Jr., Stanghellini, M. E., Reginato, R. J., Idso, S. B., Jenkins, A. D., and Jackson, R. D. 1979. Remote detection of biological stresses in plants using infrared thermometry. Science 205:585-587.

46. Schlösser, E. 1997. Allgemeine Phytopathologie. 2nd ed. Thieme Verlag, Stuttgart.

47. Smith, R. C. G., Heritage, A. D., Stapper, M., and Barrs, H. D. 1986. Effect of stripe rust (Puccinia striiformis West.) and irrigation on the yield and foliage temperature of wheat. Field Crops Res. 14:39-51.

48. Spencer, D. M. (ed.) 1981. The Downy Mildews. Academic Press, London.

49. Wisniewski, M., Lindow, S. E., and Ashworth, E. N. 1997. Observations of ice nucleation and propagation in plants using infrared video thermography. Plant Physiol. 113:327-334.

50. Zitter, T. A., Hopkins, D. L., and Thomas, C. E. 1996. Compendium of Cucurbit Diseases. The American Phytopathological Society, St. Paul, $\mathrm{MN}$ 